\title{
0 igual e o diferente: essência, devir e representação de identidades. Leitura da revista Comunicação \& Cultura, n. 1 - A cor dos media, dirigida por Isabel Capeloa Gil (Lisboa, Quimera, 2006)
}

Rafael Paes Henriques*

Definir a identidade cultural de um povo pode significar duas tarefas completamente distintas. Tudo depende de qual é o princípio de unidade adoptado; varia de acordo com o lugar em que se assenta o fundamento de identidade. Num primeiro viés, ela é determinada por uma essência fixa; por uma semelhança de origem histórica que deve ser resgatada. Nesse sentido, a identidade encontra-se num passado homogeneizante, fixo e estável, que é passível de ser recuperado.

Por outro lado, a identidade cultural pode ser decidida na duplicidade da dinâmica entre semelhança e diferença. Mais do que uma experiência primeira essencializada que deveria ser retomada, nessa perspectiva, a identidade se estabelece, necessariamente, desde aquilo em que um povo se tornou. Com efeito, ela nunca está pronta ou completa; não é inalterável, mas sim devir. Não se dá fora da representação, pois é sempre posicionamento. É um tornar-se, a partir de determinados enquadramentos. «[...] as identidades são os nomes que damos às diferentes formas como somos posicionados pelas narrativas do passado e como nos posicionamos dentro delas» (Hall: 24).

Ao se conceber a delimitação das identidades enquanto produção de algo, ganha-se o carácter processual e criativo do fenómeno, que passa a ser «[...] uma condição activa e não passiva, a partir da qual e através da qual se disputam interesses antagónicos que são usados nas representações culturais, sociais, políticas [...]» (Faria e Almeida: 124).

É nesse segundo horizonte de interpretação que se situam os artigos da revista Comunicação \& Cultura - A cor dos media. Centrando atenção nas implicações teóricas - como, por exemplo, os trabalhos já citados - e também em investigações teórico-empíricas sobre os processos de representação das identidades, os artigos se ocupam de compreender melhor esses processos e em descrever o lugar e as tarefas executadas pelos media.

A importância da comunicação, como mecanismo de produção e reprodução de sentidos, na construção das identidades colectivas é inegável. Dessa forma, as investigações apresentadas na revista são um contributo importante para a ilustração de determinados aspectos dessas práticas.

É certo que os novos media intensificaram a troca de ideias e o contacto entre diferentes culturas. E o aumento dos fluxos no mundo contemporâneo não se restringe ao campo da comunicação, mas também pode ser verificado no comércio internacional, no mercado de capitais e nos movimentos migratórios. Nesse contexto, Roberto 
Carneiro (pp. 37-55) avalia as questões das identidades nacionais a partir do fenómeno da hibridação. "Efectivamente, o motor do desenvolvimento é cada vez mais conexo com a ideia de combinação criativa de diferentes e de pluralismo cultural» (p. 47). Para que isso se efective, o desafio é reconhecer no outro uma pessoa plena em capital humano, social e cultural capaz de enriquecer todos os outros.

Mas nem sempre é assim. Isso porque a rádio, o cinema, a TV e os outros media muitas vezes são actores decisivos de uma estrutura de duplo movimento: ao mesmo tempo que podem reproduzir estereótipos sociais, acabam por ajudar a reforçá-los. Os artigos de Isabel Ferin (pp. 73-97) e Catarina Valdigem (pp. 99-115) são bons exemplos de como determinados grupos minoritários - ciganos e brasileiros - são segregados mediaticamente. Ou são raramente representados, ou então são caracterizados em enquadramentos semânticos que sempre ressaltam aspectos negativos. $\mathrm{Na}$ investigação de Ferin, foram analisados, por meio de entrevistas em profundidade e de sessões de grupo de foco, como as mulheres brasileiras e ciganas percebem matérias jornalísticas em que são retratadas, e que consequências esses enquadramentos trazem as suas vidas. As ciganas reconheceram, na peça assistida, o prolongamento das «[...] relações existentes entre a sociedade dominante e a minoria cigana» (p. 94). As mulheres brasileiras têm a percepção de que determinados «[...] estereótipos existentes na sociedade portuguesa, encontram eco nas notícias sobre as mulheres prostituídas brasileiras, acentuando a discriminação e interferindo nos quotidianos de todas as outras mulheres» (p. 94).

A partir de um amplo corpus fruto das emissões televisivas dos canais generalistas portugueses, durante o prime-time, Valdigem concluiu que os brasileiros aparecem na ficção televisiva exibida em Portugal, quando as produções são de origem brasileira "[...] conferindo destaque especial a situações do quotidiano, em que as relações afectivas, o matrimónio e o desporto e lazer assumem uma vincada predominância» (p. 110). Já os ciganos praticamente não são representados, em todos os géneros televisivos, «[...] observando-se a inexistência de imagens desta comunidade na publicidade» (p. 111).

$\mathrm{Na}$ análise e distinção de três momentos da telenovela em Portugal, - as primeiras exibições, a hegemonia das produções brasileiras e a ascensão da telenovela portuguesa - Catarina Duff (pp. 57-71) identifica a importância do diálogo com o "outro" na construção de uma narrativa e de uma identidade nacional. É que, quando, em 1982, surgiram as primeiras telenovelas produzidas em Portugal, o «modelo discursivo de estruturação textual e semântico» (plano linguístico) e "os enredos, narrativas, papéis e actores» (plano social) da telenovela brasileira já estavam bem enraizados em Portugal. Assim, criou-se a necessidade de distinção do “eu” e do "outro" realizada por meio de um «sistema classificatório original, através do desenvolvimento de histórias de ficção nacionais» (p. 66).

O cinema é outra ferramenta de muita valia na produção de identidades colectivas. Marcos Ferreira (pp. 135-155) debruçou-se sobre um bom exemplo desse processo. Sua investigação analisou a relação do filme Underground (1995), de Emir Kusturica, 
com os modelos de construção e desconstrução do balcanismo. " [...] Kusturica's narrative approach to identity is above all meant to stress the urgency of recreating the self on interactive/ambivalent grounds» (p. 148).

Já o olhar de Luís Bonixe (pp. 157-169) se volta para a função social das rádios locais na preservação e reprodução das identidades locais. O potencial desses veículos com menores infra-estruturas assenta na privilegiada proximidade com o ouvinte. «As rádios locais facilitariam a abertura da agenda dos media, permitindo que novos temas e novos protagonistas entrassem na cena mediática» (p. 162). Na investigação para a sua dissertação de mestrado, Bonixe avaliou o caso de quatro emissoras do distrito de Setúbal e verificou que esse potencial não está sendo explorado. $O$ espaço que poderia ser usado para o debate, e para representar com mais fidelidade as variadas vozes das comunidades locais, é ocupado, na maioria das vezes, por representantes das elites regionais. São elas quem mais frequentemente "aparecem" no noticiário. 